\title{
Forskningsnote
}

Vi har i redaktionen for Dansk Sociologi diskuteret muligheden for at introducere nye formater, der kan være med til at gøre cirkulationen og diskussionen af dansk sociologisk forskning endnu bedre. I forlængelse heraf præsenterer vi nu artikelformatet "Forskningsnote". Formatet er defineret således:

- En forskningsnote præsenterer i kort form nyere resultater inden for den sociologiske forskning. Der kan være tale om resultater af teoretisk eller empirisk arbejde, og arbejde inden for alle fagområder, teoretiske traditioner og metoder er velkomne.

- En forskningsnote skal fokusere på at præsentere forskningsresultater på en lettilgængelig måde, meget gerne med brug af figurer, billeder, tabeller eller modeller.

- En forskningsnote skal kunne rummes på 5 sider (12.000 anslag), eksklusiv henvisninger, figurer og tabeller. Hertil kommer et abstract på max. 200 ord.

Vi præsenterer på de næste sider tidsskriftets første forskningsnote. Vi håber, at vores læsere i fremtiden vil tage det nye format til sig, så vi i de kommende numre kan præsentere flere nye forskningsresultater. 


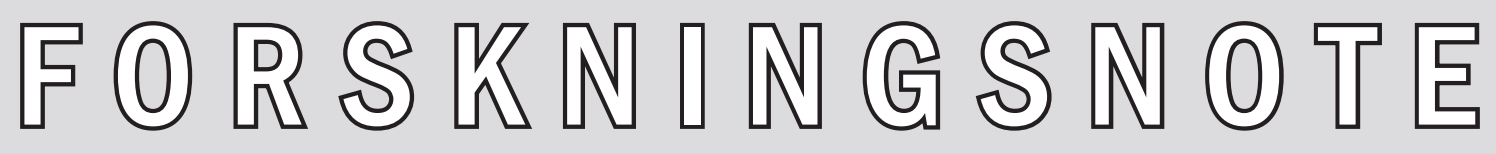

Af Anton Grau Larsen og Christoph Houman Ellersgaard

\section{Det tværgående magtnetværk \\ - Magteliten som toppen af de vigtigste sektorer i Danmark}

Denne forskningsnote identificerer den danske magtelite og undersøger dens sammensætning ved hjælp af netværksanalyse anvendt på det samlede danske magtnetværk 2012-13. Der gives en beskrivelse af tværsektorielle forbindelser i magtnetværket med særligt fokus på magtelitens betydning for sammenhængskraften i netværket. Det samlede magtnetværk består af 5.079 affiliations-netværk, som er indsamlet ved hjælp af den såkaldt inklusive metode. En kerne på 423 personer identificeres (magteliten), hvor koncentrationen af magtfulde forbindelser er særlig stor. Kernen er domineret af erhvervslivet, men er ligeledes et integrerende led mellem institutioner fra erhvervsliv, stat, fagbevægelse og uddannelses- og forskningsverden. Vi beregner desuden odds-ratio for sektorspecifik netværkscentralitet og finder, at personer fra sektorer, som er velrepræsenteret i kernen, har betydeligt højere sandsynlighed end forventeligt for at være velforbundne i andre sektorer.

Søgeord: elite, magt, netværk, elite integration, institutionelle ordner. 


\section{Baggrund: De tværgående magtnetværk}

7 or 15 år siden konkluderede Magtudredningens eliteundersøgelse, at "der ikke findes én magtelite i Danmark i 1999, men flere mere eller 1 mindre autonome eliter" (Christiansen, Møller \& Togeby 2001:241). Ifølge undersøgelsen var der ikke tegn på tværgående netværk mellem de vigtigste sektorer i det danske samfund. Denne artikel - baseret på arbejdet i vores Ph.d.-afhandlinger (Ellersgaard 2015; Larsen 2015) - sætter alvorligt spørgsmålstegn ved disse resultater. Vi undersøger dels forbindelser på tværs af sektorielle netværk, og dels hvilke sektorer der er repræsenteret i kernen af magtnetværket.

Vi tager udgangspunkt i C. Wright Mills' (1956:18) begreb om magteliten som "de overlappende kliker" i toppen af de "centrale institutionelle ordner" - samfundets vigtigste sektorer. Med et nærmere blik på, hvem der interagerer på tværs af vigtige samfundssektorer, kan man ifølge Mills kvalificere, hvem der tilhører magteliten i et givent samfund. På den måde gøres afgræsningen af magteliten - altså dens størrelse og sammensætning - til et empirisk spørgsmål frem for at blive bestemt af forskeren på forhånd (jf. Knoke 1993), som det var tilfældet i Magtudredningens eliteundersøgelse.

Den klassiske pluralistiske kritik af begrebet om magteliten hævder blandt andet, at magtelitens evne til at gøre sig gældende på tværs af autonome sektorer er begrænset (Dahl 1958). Derfor undersøges sandsynligheden for at indtage centrale positioner i sektorspecifikke netværk betinget af positionen $i$ andre sektorspecifikke netværk. For eksempel sandsynlighed for at have en central post i videnskabelige affiliations-netværk, når man har en central post i erhvervsnetværket. Desuden undersøges, i hvilket omfang centrale poster i det danske magtnetværk er koncentreret på få hænder.

\section{Data og Metode: Elitenetværk}

Vi har gennem 2012 og 2013 opbygget en komplet database over alle 5.079 offentligt tilgængelige affiliations-netværk - bestyrelser, udvalg, råd og nævn - bestående af samlet 56.536 poster og 37.750 unikke personer (se tabel 1, for yderligere detaljer om dataindsamling og adgang til data, se Ellersgaard \& Larsen 2015). Affiliations-netværk er fundet gennem en såkaldt inklusiv metode. Alle potentielt magtfulde offentligt tilgængelige affiliations-netværk er omfattet og kan derfor betragtes som en totalpopulation af potentielt magtfulde poster i det danske samfund. Under 1 pct. af den voksne danske befolkning er at finde i magtnetværket.

Disse affiliations-netværk er imidlertid forskelligartede, hvorfor de vægtes efter størrelse. Det vægtede netværk benyttes til at se på fordelingen af centrale poster blandt de 7.249 personer, som har flere end én vægtet post (se figur 2). Affiliations-netværkene er desuden kategoriseret efter, hvilken sektor de fungerer indenfor, således at et udvalg i Dansk Metal fx kodes "Industri" og "Fagforening". Disse koder benyttes i figur 1 til at identificere sektorielle 


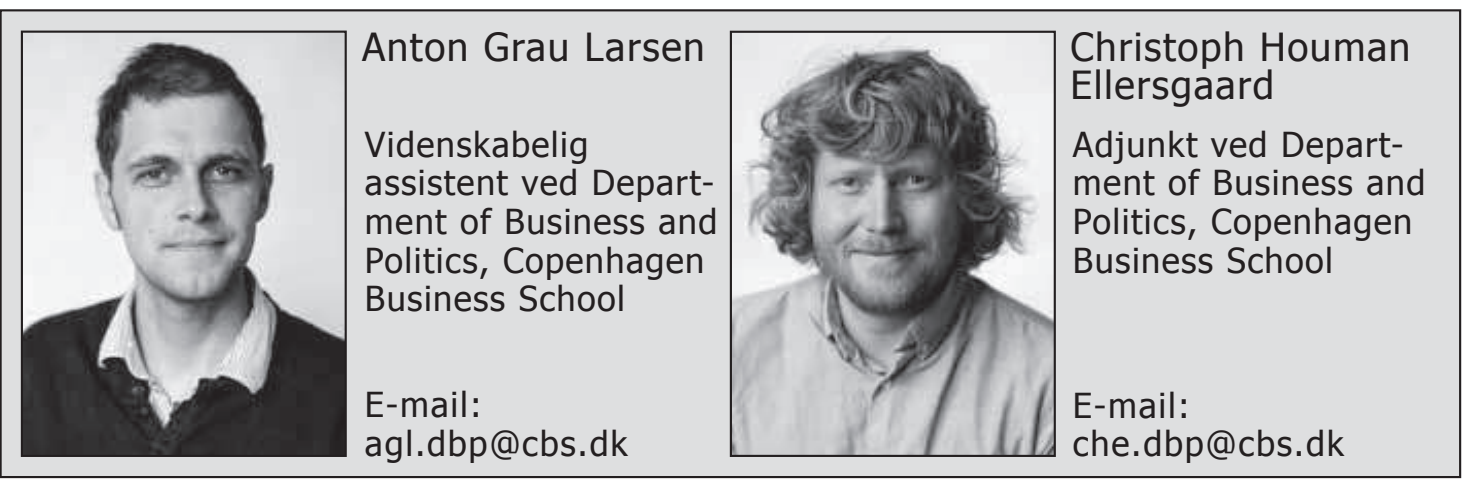

undernetværk. Herefter identificeres personer, der har poster inden for de 10 pct. mest centrale affiliations-netværk i hvert undernetværk, der, vægtet som beskrevet ovenfor, har den største rækkevidde i undernetværket. Rækkevidden er antallet af forbindelser, som et affiliations-netværk når ud til gennem bestyrelsesmedlemmernes øvrige poster, vægtet efter affiliations-netværkets størrelse. Herefter beregnes odds-ratio for at have henholdsvis centrale og ikke-centrale poster i de øvrige sektorielle netværk afhængigt af, om man har centrale poster i et andet netværk sammenlignet med alle 37.750 øvrige i magtnetværket.

Tabel 1. Datakilder.

\begin{tabular}{lrrrrr}
\hline \hline Type af netværk & Fra original kilde & Ekskluderet* & $\begin{array}{r}\text { Tilføjet gennem } \\
\text { snowball }\end{array}$ & $\begin{array}{r}\text { Antal } \\
\text { netværk }\end{array}$ & $\begin{array}{r}\text { Antal } \\
\text { poster }\end{array}$ \\
\hline Stat $^{1}$ & 2.306 & 1.770 & 314 & 850 & 10.254 \\
Folketing $^{1}$ & 153 & 101 & 31 & 83 & 970 \\
Organisationer $^{1}$ & 749 & 181 & 922 & 1.490 & 16.434 \\
Virksomheder $^{2}$ & 1.136 & 85 & 40 & 1.091 & 7.476 \\
Fonde $^{2}$ & 1.380 & 69 & 83 & 1.394 & 8.181 \\
VL-grupper $^{3}$ & 117 & 3 & 0 & 114 & 3.845 \\
Kommissioner $^{4}$ & 116 & 44 & 0 & 72 & 1.121 \\
Begivenheder $^{5}$ & 74 & 65 & 8 & 17 & 8.253 \\
\hline \multirow{2}{*}{ Total } & & & & & \\
\hline \hline
\end{tabular}

* Netværk blev fjernet hvis de ikke havde en bestyrelse med medlemmer udenfor organisationen selv, der ikke kunne findes information om bestyrelsen hverken på nettet eller ved personlig kontakt, bestyrelsen allerede var i data fra andre kilder eller bestyrelsen medlemmer var totalt enslydende med en anden bestyrelse i samme organisation. Alle netværk skulle desuden indeholde en komplet medlemsliste og mødes fysisk.

tIndeholder såvel underudvalg som de 142 netværk fundet gennem snowball of prominente aktørers netværk.

1. Kilde: Alle statslige institutioner på over-regionalt niveau samt alle foreninger med høringsret og alle underudvalg i disse hentet via www.foa.dk.

2. Kilde: 1000 største virksomheder og vigtige strukturvirksomheder fra CVR-registret ved hjælp af www.biq.dk.

3. Kilde: www.vl.dk.

4. Kilde: Registrering af politiske kommissioner mellem 2005-11 af A4 suppleret af forfatterne op til 2013.

5. Kilde: (www.kongehuset.dk) og journalisters privatarkiv. 


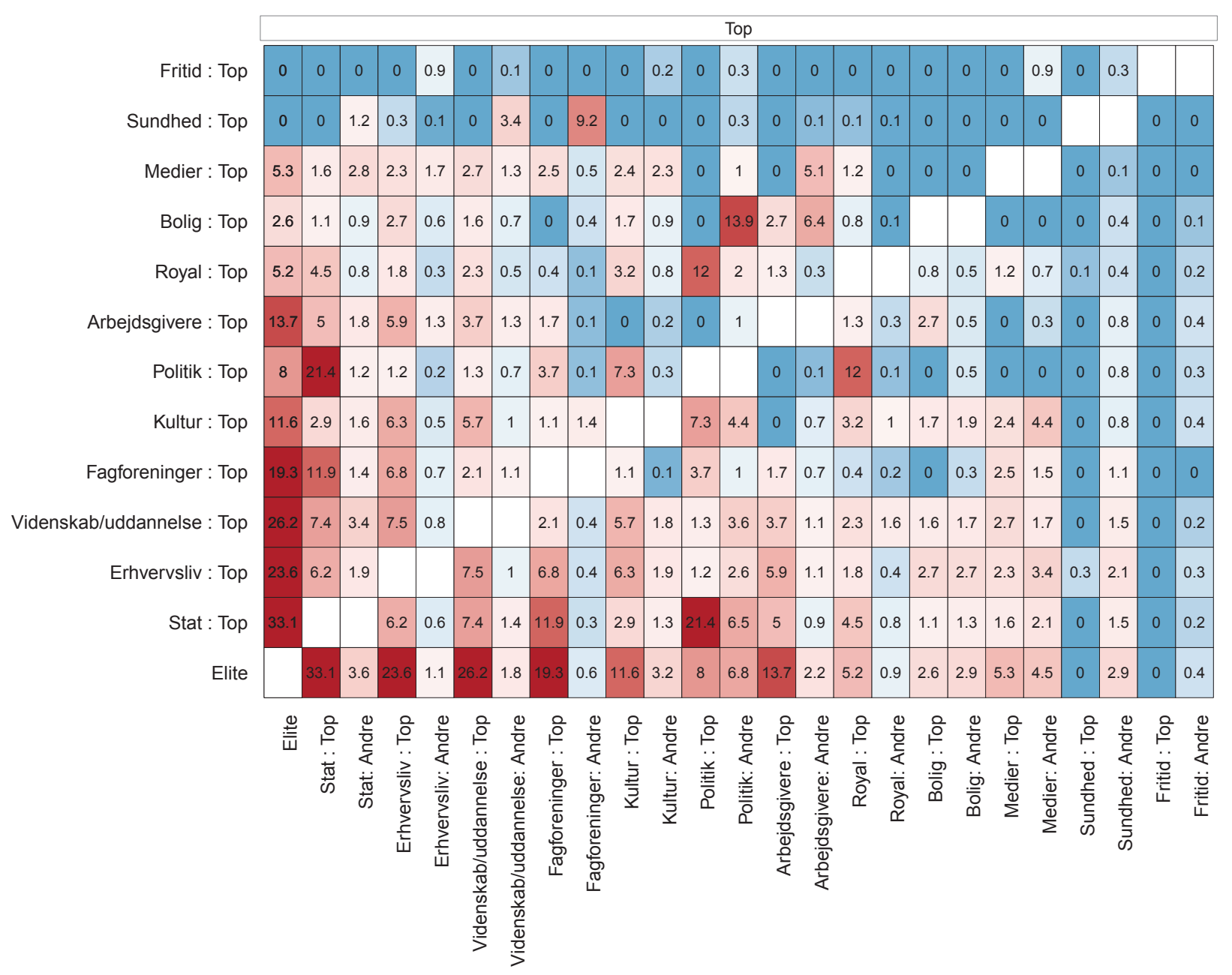

Figur 1. Odds-ratioer for at have topposition i sektornetværk, betinget af toppositioner $\mathrm{i}$ andre sektorer.

Endelig benyttes den sociometriske afstand mellem personerne til at finde en kerne i magtnetværket (Doreian \& Woodard 1994; Seidman 1983). Kernen er den gruppe, hvorfra ikke flere kan fjernes, før den inderste gruppe begynder at blive svagere internt forbundet (for yderligere detaljer om identifikation af magteliten, se Ellersgaard \& Larsen 2014). Denne kerne og den sektor, dens medlemmer tilhører, identificeret ved deres nuværende eller sidste arbejdsplads, er illustreret i figur 3, som er vedlagt separat.

\section{Resultater: Magtens tiltrækningskraft}

Ser man på odds-ratioer for at sidde i toppen af andre sektornetværk betinget af placering i toppen af et sektornetværk i figur 1, er det tydeligt, at centrale positioner avler centrale positioner. Særligt positioner i toppen af statens, virksomhedernes, uddannelsesverdenens, interesseorganisationernes og fagforeningernes sektornetværk gør det langt mere sandsynligt at ind gå i toppen af de øvrige af de selvsamme sektornetværk. Fx har personer med en placering i de 10 pct. mest centrale affiliations-netværk inden for erhvervslivet 


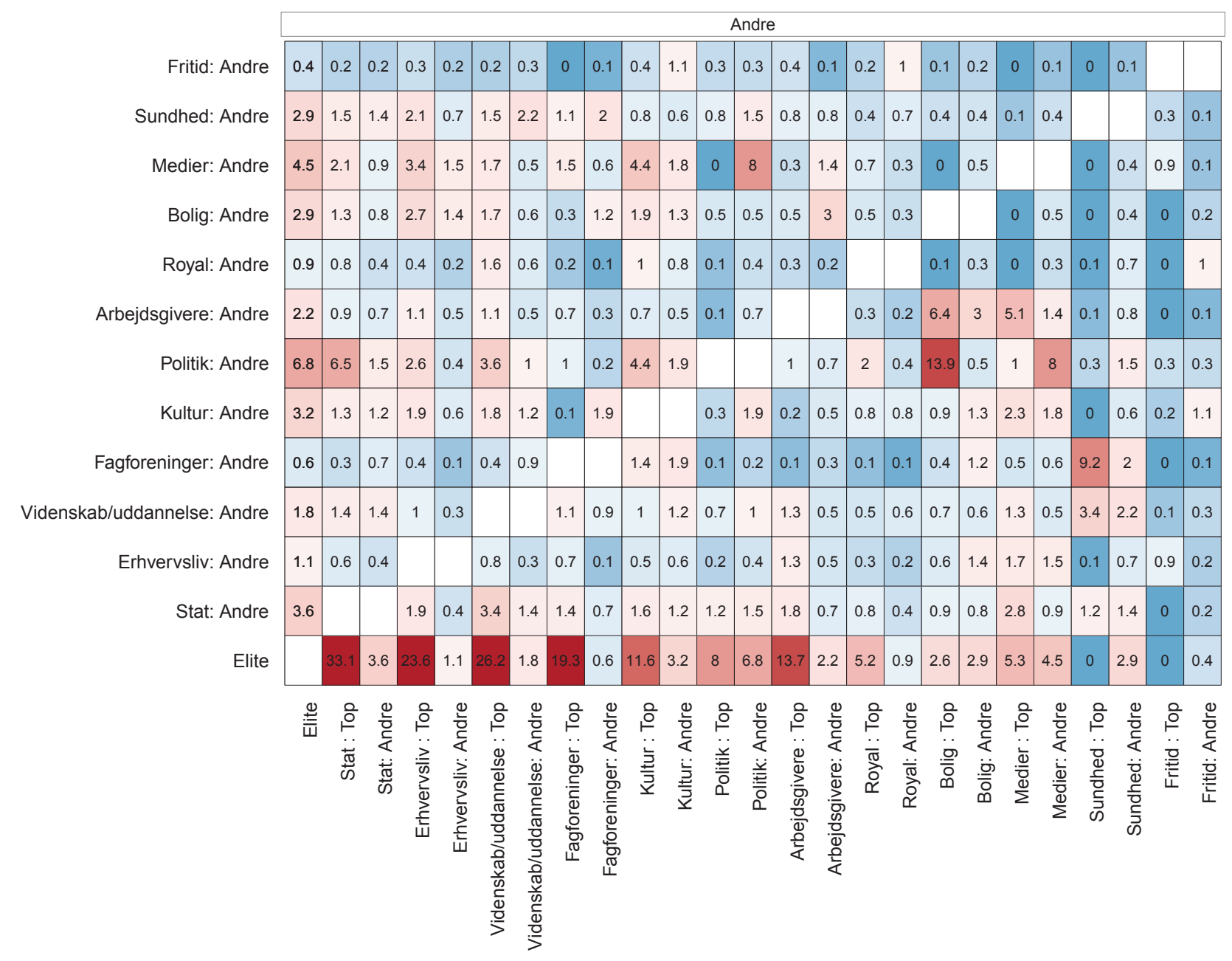

Odds-ratio beregnes i forhold til de øvrige 37.750 personer i magtnetværket. Toppositioner defineres ved at sidde i et udvalg, bestyrelse eller andet netværk, der er blandt de 10 pct. mest centrale indenfor en sektors eget netværk. Øvrige positioner benævnes "andre". Farven angiver odds-ratios størrelse. Jo mere rødt, desto mere oversandsynlig er forbindelser mellem sektorer, jo mere blåt desto mindre sandsynligt.

(N=815) 6,2 gange større chance for at være at finde blandt de 10 pct. mest centrale statslige affiliations-netværk $(\mathrm{N}=415)$. Bemærk at odds-ratioer kun beregnes i forhold til dem, der allerede har en post i magtnetværket, dvs. personer med to eller flere poster. Når den øvrige danske befolkning bruges som målestok, er odds-ratioer ca. 100 gange højere.

Tydeligst er magtens koncentration, når vi ser på de 423 personer, vi identificerer som magteliten. Her er odds-ratioer for at have en topplacering i de fleste øvrige sektorer væsentligt højere end for personer, der har topposter i de øvrige netværk. Institutionelt set når magteliten bredt ud. Dog fremgår det også, at nogle sektor-specifikke netværk, som knytter sig til sport og fritid, sundhed og medier, ikke rækker ind i magtens kerne.

I figur 2 bestyrkes billedet af, at posterne i det danske magtnetværk samles på få hænder. En gruppe på omkring 500 personer rykker for alvor fra de øvrige 7.249, som har flere end én vægtet post, når man ser på fordelingerne 
Figur 2. Koncentration af poster i det danske magtnetværk.
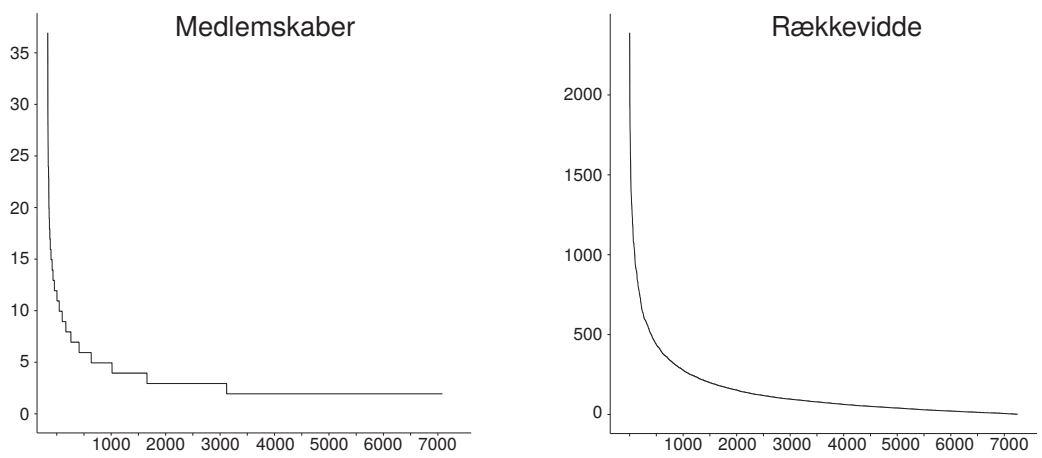

Blandt de 7.249 personer med mere end en post er såvel antallet af medlemskaber som rækkevidden af personernes netværk meget skævt fordelt. Rækkevidden er antallet af personer en person enten er direkte forbundet til eller maksimalt er ét led fra, når forbindelserne vægtes efter størrelse.

af antallet af medlemskaber og rækkevidde i magtnetværket. Ni tiendedele af disse har fx under ti poster, mens enkelte kommer op på næsten 40 poster. Ser man på antallet af personer inden for rækkevidde i magtnetværket, dukker samme billede op. 90 pct. når kun ud til maksimalt 500 øvrige personer, mens enkelte når ud til mere end 2.300. På mange måder følger fordelingen af poster det berømte Mattheus-princip (jf. Merton 1968). Centrale poster avler centrale poster.

Ser vi på forbindelserne internt i magteliten, se figur 3, er det tydeligt, at bestemte grupper dominerer. Stærkest står erhvervslivets ledere (44 pct.), der sammen med lederne i arbejdsgiverorganisationerne ( 9 pct.) udgør mere end halvdelen af magteliten. Også stat og politik (18 pct.), fagforeningerne (13 pct.) og forskning og uddannelse (12 pct.) udgør vigtige sektorer, mens landbrugets organisationer stadig sætter spor og udgør 3 pct. af magtnetværket. Til disse skal tilføjes alle ledere af fødevarevirksomheder. Derimod er både medieverdenen, hæren, det juridiske felt, de gejstlige og kultureliten svagt repræsenteret eller fraværende. Magteliten består desuden primært af ledere med undtagelse af enkelte forskere, primært økonomer. Således er de 8 pct. politikere enten nuværende eller tidligere ministre, borgmestre eller regionsrådsformænd.

Vores visualisering af magtelitens netværk viser også, at især fagbevægelsen (de røde cirkler) udgør en klike, der dog også har forbindelser til de øvrige sektorer. Ligeledes udgør erhvervslivets inderkreds (Useem 1984) en samlet sektor, men i modsætning til fagbevægelsen er den uden klar spydspids i elitenetværket. Personer med tilknytning til forskning og uddannelse er derimod placeret mere spredt i magtelitens netværk og har altså en svagere intern organisering. Fremfor alt bør det dog bemærkes, hvor mange forbindelser der stadig går på tværs og forbinder de centrale sektorer i den danske magtelite.

\section{Diskussion: Magteliten i konkurrencestaten}

De mange, tætte forbindelser mellem nogle af disse sektorer betyder, at netop disse grupper kan betragtes som en dansk magtelite: den organiserede magt i Danmark. Samtidig viser oversandsynlighederne for at sidde i toppen af 
netværk tilhørende forskellige sektorer, at der findes en gruppe, hvis netværk går på tværs af disse sektorer i Danmark. Forestillingen fra Magtudredningen om flere uafhængige eliter må således korrigeres.

Magtelitens netværk indikerer en alliance mellem erhvervsliv, politik, stat, fagbevægelse og forskning, der samler disse gruppers fælles interesser i et konkurrencedygtigt Danmark. Men gruppernes placering i dette netværk tyder på, at de både må gå på kompromis med de øvrige institutionelle sektorer i magteliten, men også på at deres eksistensberettigelse respekteres, når fremtidens Danmark lanceres. Det kunne forklare, at disse grupper ligeledes har en central position i den danske version af konkurrencestaten (jf. Pedersen 2011).

En netværksanalyse kan ikke afgøre, hvilken indflydelse de 423 opnår gennem deres formelle forbindelser og positioner. Ligeledes kan alle sektorers især måske i politik og medier, hvor eliternes uafhængighed oftere beklikkes - forbindelser ikke nødvendigvis indfanges lige godt. På trods af disse indvendinger står billedet af en lille gruppe, der monopoliserer potentielt magtfulde poster og kontakter på tværs af sektorer, tydeligt frem i resultaterne. $\mathrm{Nu}$ er bolden givet op til nærmere undersøgelser af de institutionelle ordner, der dominerer Danmark. Ønsker man at undersøge netværket yderligere er data frit tilgængelige på www.magtelite.dk.

\section{Litteratur}

Christiansen, Peter Munk; Birgit Møller \& Lise Togeby 2001: Den Danske Elite. København: Hans Reitzels Forlag.

Dahl, Robert A. 1958: "A Critique of the Ruling Elite Model". The American Political Science Review, 52(2):463-69.

Doreian, Patrick \& Katherine L. Woodard 1994: "Defining and Locating Cores and Boundaries of Social Networks". Social Networks, 16(4):267-93.

Ellersgaard, Christoph Houman 2015: Elites in Denmark: Power Elites and Ruling Classes in a Welfare State. Ph.D. Dissertation, Department of Sociology, University of Copenhagen.

Ellersgaard, Christoph Houman \& Anton Grau Larsen: "Data Exchange Network: The Danish Elite Network". Connections, 35, no. 1, 2015.

Ellersgaard, Christoph Houman \& Anton Grau Larsen 2014: "Identifying Power Elites - a Social Network Analytic Approach". Lausanne: Conference paper at Understanding the transformation of economic Elites in Europe.

Knoke, David 1993: "Networks of Elite Structure and Decision Making". Sociological Methods E Research, 22(1):23-45.

Larsen, Anton Grau 2015: Elites in Denmark: Identifying the Elite. Ph.D. Dissertation, Department of Sociology, University of Copenhagen.

Merton, Robert K. 1968: "The Matthew Effect in Science". Science, 159(3810):56-63.

Mills, Charles Wright 1956: The Power Elite. Oxford: Oxford University Press.

Pedersen, Ove Kaj 2011: Konkurrencestaten. København: Hans Reitzels Forlag.

Seidman, Stephen B. 1983: "Network Structure and Minimum Degree". Social Networks 5(3):269-87.

Useem, Michael 1984: The Inner Circle. New York: Oxford University Press. 


\section{Figur 3: Magtelitens netvark i Danmark}

\section{Sektorer:}
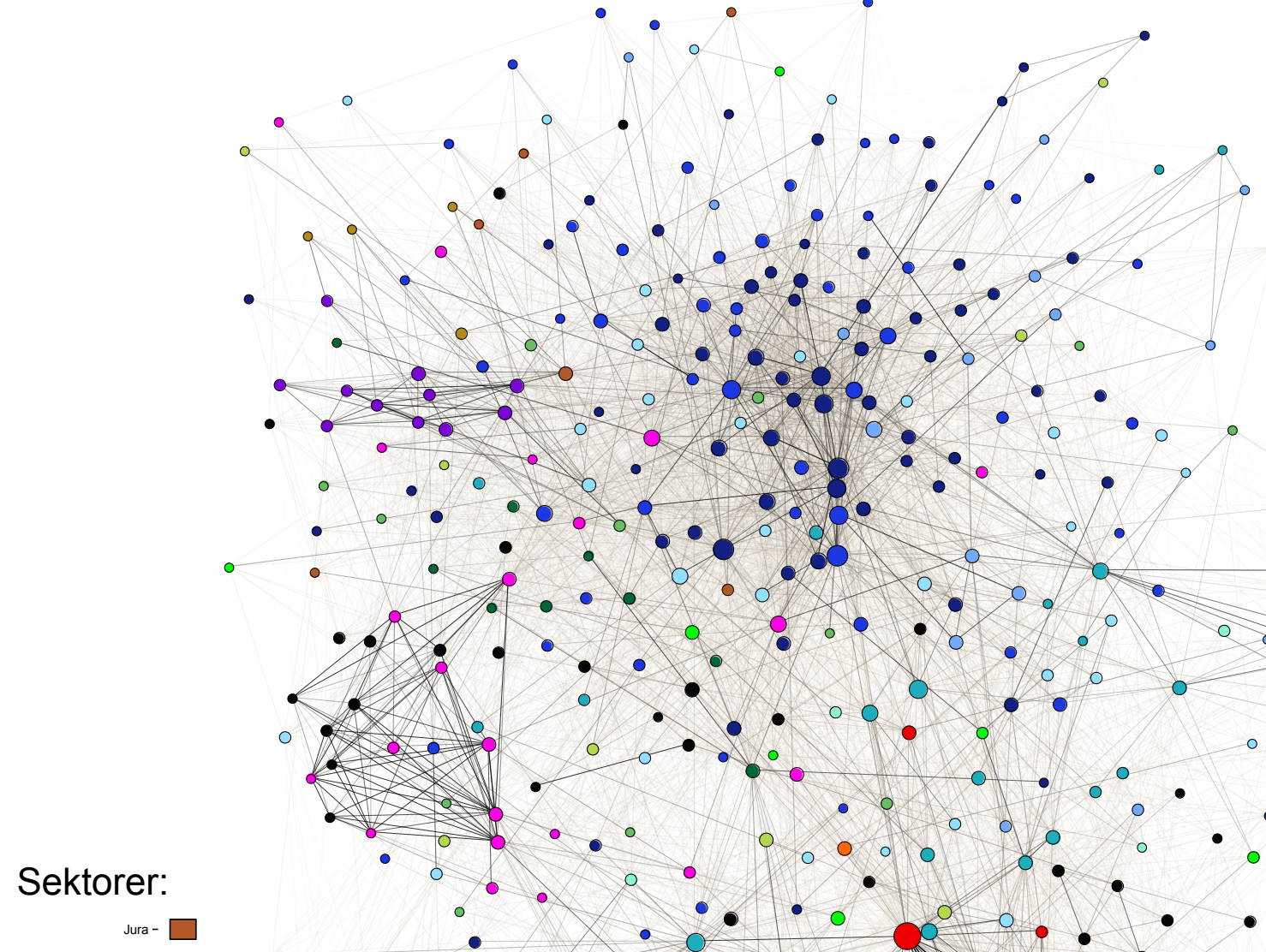

Kultur og velgørenhed - $\square$

or og statskundskabere-
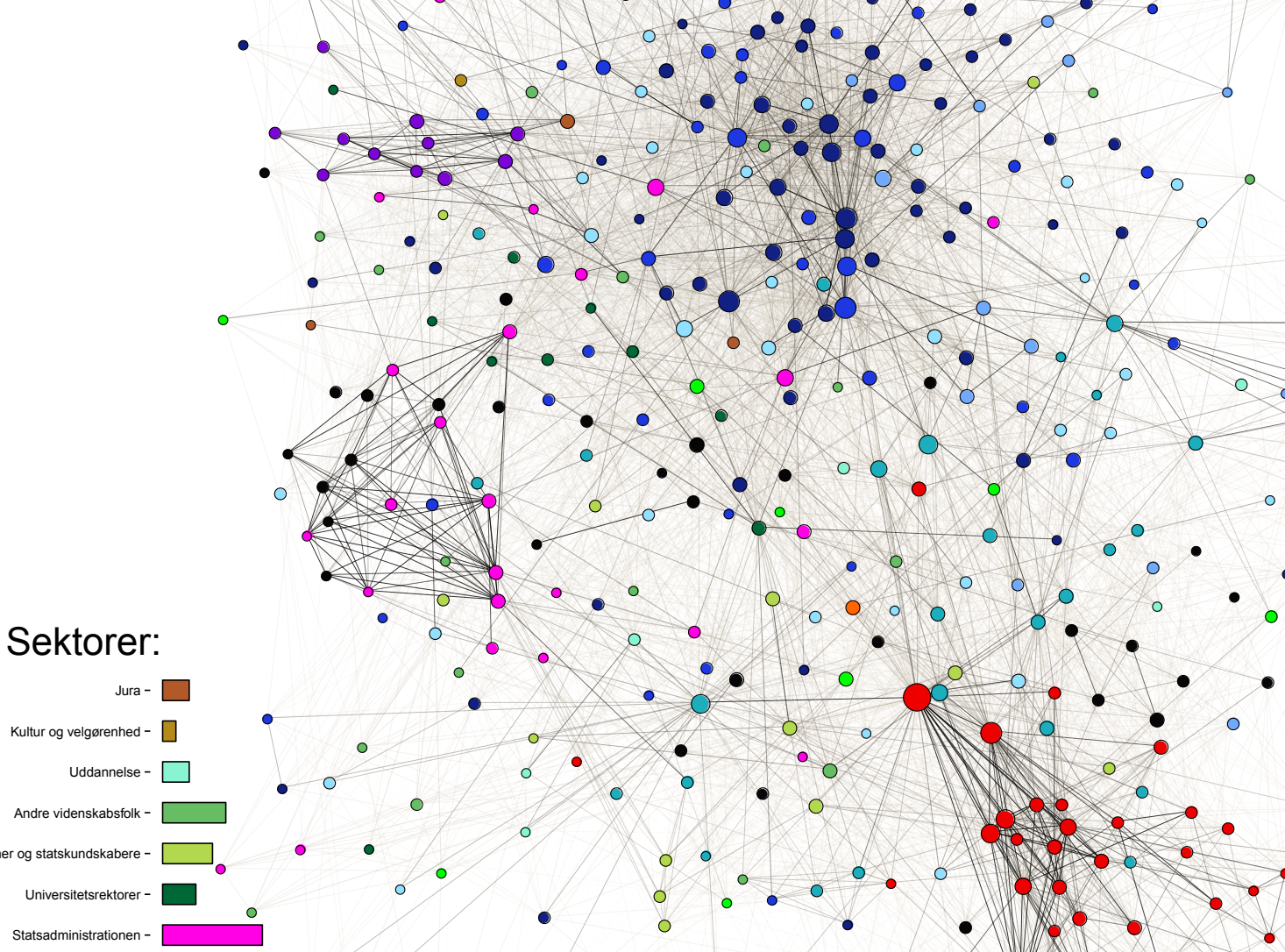

\section{。}
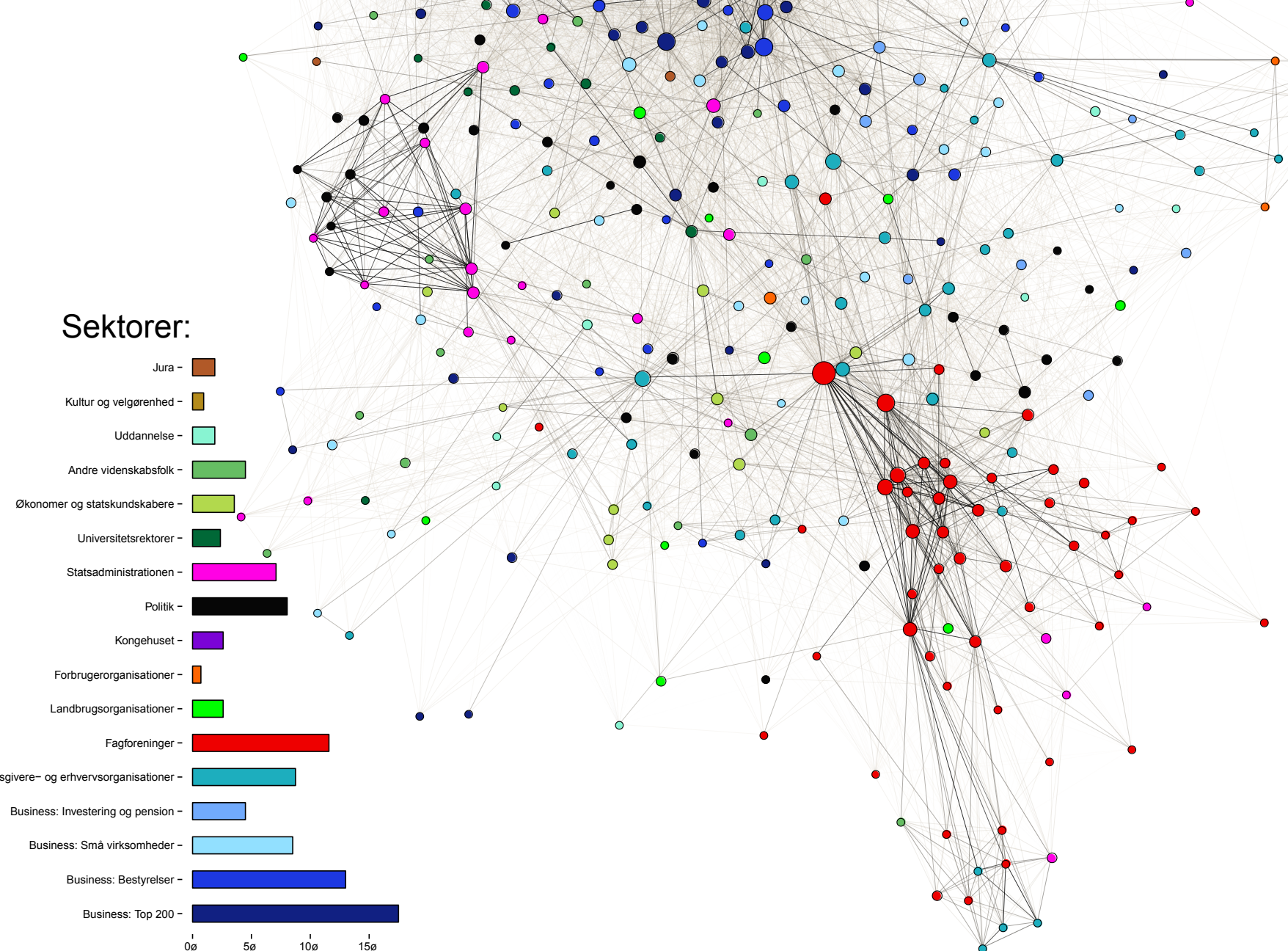

Magtnetværket for de 423 personer i kernen af det danske magtnetværk efter deres sektortilknytning. Ikonernes størrelse afgøres af deres samlede rækkevidde i netværket. Stregernes tykkelse afgøres af forbindelsernes styrke, altså antallet af forbindelser mellem to personer og størrelsen af de netværk, hvor de kender hinanden. 